\title{
A Review of Microsatellite Markers and their Application on Genetic Diversity Studies in Parrots
}

\author{
Flavia T. Presti, Adriane P. Wasko \\ Department of Genetics, Institute of Biosciences, São Paulo State University, Botucatu, Brazil \\ Email: flapresti@hotmail.com
}

Received 20 February 2014; revised 18 March 2014; accepted 7 April 2014

Copyright (C) 2014 by authors and Scientific Research Publishing Inc.

This work is licensed under the Creative Commons Attribution International License (CC BY). http://creativecommons.org/licenses/by/4.0/

(c) (i) Open Access

\section{Abstract}

The ability of a population to adapt to a changing environment depends on its genetic variation. Thus, the study of genetic diversity within and among species or populations is especially important on conservation biology scopes. One way to assess the genetic diversity is through the use of microsatellite molecular markers. Microsatellites have been widely used to answer population genetics issues as gene flow, parentage, and population structure, mostly resulting in data on the distribution of genetic variability within and among natural populations, which are essential for ex situ and in situ conservation procedures. As the Psittacidae family comprehends one of the birds group with the largest number of endangered species, studies that aim to investigate the genetic diversity of these animals may support their conservation. This article is a review of genetic data on parrots, through the use of microsatellite markers, that have been published since 2004.

\section{Keywords}

Genetic Diversity, Microsatellite, Parrots

\section{Introduction}

From the year 1600 until today it is estimated that many organisms have become extinct in wild environments, a fact that reflects on an accelerated loss of species that exceeds the natural rate of extinction. There are several causes of this loss, but one of the most important factors is habitat destruction mainly caused by human activity [1]. In some cases, human intervention is needed to ensure the survival of species and their populations. Taking into account this scenario, there is currently a great concern for biodiversity preservation in order to prevent the 
extinction of other species. The definition of biodiversity includes not only the ecological variability (number of species in a community and their interactions), but also the genetic variability that is essential for natural selection, and thus to the evolution of species. Therefore, the International Union for Conservation of Nature (IUCN) recognizes the requirement to conserve the genetic diversity as one of the three global conservation priorities (World Conservation Strategy, IUCN-UNEP-WWF, 1980).

Nowadays, several techniques are available for the detection of genetic diversity, i.e. for identifying DNA polymorphism, including the microsatellite ones. This marker is easily amplified by PCR, requiring no large initial amounts of DNA samples. Another advantage of its use compared to other molecular markers is the fact that it has high polymorphism due to a large variation in the number of repetitions. Furthermore, the microsatellite loci have co-dominant multi-allelic expression which permits the discrimination of homozigous and heterozigous genotypes, facilitating the characterization of different populations by allele frequency analysis [2]. Therefore, genetic diversity data, based on microsatellites, can be used for monitoring the genetic variability of species and support management actions to prevent the loss of genetic diversity over time. The genetic diversity obtained from microsatellite data is, in most cases, negatively correlated with the risk of extinction [3].

There are several other utilities of microsatellite markers for conservation purposes. As the intraspecific genetic variability is crucial for the persistence of species in wild environments, the diagnosis of genetic variation and how it is geographically distributed are crucial points to characterize its conservation status. Furthermore, a species may be formed by separate units [4]. When a population is divided into isolated sub populations, genetic drift can lead to loss of alleles resulting on different allele frequencies within each sub populations [5]. In the same way, knowledge of the degree of relatedness between individuals is very useful in studies of evolution and behavior [6], although the complete pedigree of individuals generally cannot be determined due to limitations such as difficulty in adults catching. Social family occurrences, which differ from biological family statements, can also restrain a robust pedigree analysis [7]. For these reasons, genetic studies are being widely deployed in this approach and microsatellites are very effective for elucidating the mating system, using data of relatedness between individuals. Another application of the analysis of kinship is the choice of founding couples for captive breeding programs. The population must be managed in order to retain as much genetic variation as possible in order to generate a viable long-term population.

One group of birds that deserves attention on conservation biology comprehends the Neotropical parrots (Family Psittacidae) that stand for one of the most threatened bird species in the world [8] [9]. Beside environmental factors such as deforestation, resource extraction, and climate change [10], also illegal trapping and nest poaching for pet trade have become major reasons for the decline of many species in wild habitats [11] [12]. Besides, the popularity of parrots in the pet trade contrasts with the lack of knowledge on their biology, population genetic structure, and phylogenetic relationships [11] [13]. The Psittacidae family is composed of approximately 374 species of macaws, parrots, and parakeets that are mainly distributed in the range of the globe between the tropics of Cancer and Capricorn. Nowadays, $26 \%$ of the species are considered as threatened related to their risk of extinction [8].

Thus, the aim of this article was to conduct a review on published data in the last 10 years (since 2004) pertinent to genetic diversity estimates based on microsatellite markers in parrots species. The survey was conducted in Google Scholar and Web of Science databases using the words "genetic diversity", "microsatellite" and "parrots".

\section{Results and Discussion}

The database search revealed 34 papers, involving 29 species, that included genetic diversity analyses using microsatellite markers (Table 1). Considering that there are approximately 374 species in the Psittacidae family, the number of publications is still reduced. Among the surveyed articles, 19 included the development of species-specific microsatellite loci and/or heterologous loci test. Moreover, some of them also compared the genetic diversity among phylogenetically related species. The other 15 articles using microsatellites were aimed to elucidate the population genetic structure, verify the existence of cryptic species, correlate the population genetic structure with vocal dialects, test the efficiency of nonivasive DNA sampling, verify the existence of extra-pair copulation throught the mating system analyses, estimate the relationship indexes to assist breeding programs in captivity, and check consequences of management of natural populations.

Ten polymorphic microsatellite loci were isolated from Eclectus parrot (Eclectus roratus) [14]. This parrot 
Table 1. Summary of the published data related to genetic studies on parrots species using heterologous (H) or specific (S) microsatellites primers, key issues and references (Ref). The Subject item refers to the microsatellites data scopes.

\begin{tabular}{|c|c|c|c|c|}
\hline Specie & $\mathbf{H}$ & S & Subject & Ref \\
\hline Eclectus roratus & & $\mathrm{X}$ & Loci isolation, Genetic diversity, Genetic mating system & [14] [15] \\
\hline Melopsitacus undulatus & & $\mathrm{X}$ & Loci isolation, Genetic diversity & [16] \\
\hline Neophema chrysogaster & & $\mathrm{X}$ & Loci isolation, Genetic diversity & [18] \\
\hline Cyanoramphus forbesi & & $\mathrm{X}$ & Loci isolation, Genetic diversity, Hybridization & [19] [20] \\
\hline Cyanoramphus auriceps & $\mathrm{X}$ & & Genetic diversity, Genetic differentiation & [21] \\
\hline Cyanoramphus novaezelandiae novazelandiae & $\mathrm{X}$ & & Genetic diversity, Genetic differentiation & [21] \\
\hline Platycercus elegans & $\mathrm{X}$ & & $\begin{array}{l}\text { Speciation, Population genetic structure, } \\
\text { Vocal variation }\end{array}$ & [26] [28] \\
\hline Amazona guildingii & & $\mathrm{X}$ & Loci isolation, Genetic diversity, Relatedness & {$[22][29][30]$} \\
\hline Amazona brasiliensis & $\mathrm{X}$ & & Genetic diversity, Cross-species amplification & [31] [41] \\
\hline Amazona pretrei & $\mathrm{X}$ & & Genetic diversity, Cross-species amplification & [31] [41] \\
\hline Amazona aestiva & $\mathrm{X}$ & & $\begin{array}{l}\text { Genetic diversity, Cross-species amplification, } \\
\text { Population genetic structure }\end{array}$ & {$[31][32]$} \\
\hline Amazona leucocephala & $\mathrm{X}$ & $\mathrm{X}$ & Loci isolation, Cryptic diversity & [33] [39] \\
\hline Amazona auropalliata & $\mathrm{X}$ & & Population genetic structure, Vocal variation & [34] \\
\hline Amazona farinosa & $\mathrm{X}$ & & Cross-species amplification, Genetic diversity & [36] \\
\hline Amazona collaria & $\mathrm{X}$ & & Genetic diversity, Relatedness & [37] \\
\hline Amazona agilis & $\mathrm{X}$ & & Genetic diversity, Relatedness & [37] \\
\hline Ara ararauna & $\mathrm{X}$ & $\mathrm{X}$ & $\begin{array}{l}\text { Loci isolation, Cross-species amplification, DNA } \\
\text { extraction of molted feather, Population genetic structure }\end{array}$ & $\begin{array}{c}{[35][36][38]} \\
{[41][43]}\end{array}$ \\
\hline Ara chloropterus & $\mathrm{X}$ & & $\begin{array}{l}\text { Cross-species amplification, Genetic diversity, DNA } \\
\text { extraction of molted feather }\end{array}$ & $\begin{array}{c}{[36][38][41]} \\
{[46]}\end{array}$ \\
\hline Ara тасао & $\mathrm{X}$ & & $\begin{array}{l}\text { Cross-species amplification, Genetic diversity, DNA } \\
\text { extraction of molted feather }\end{array}$ & [36] [38] [46] \\
\hline Ara severus & $\mathrm{X}$ & & Cross-species amplification, Genetic diversity & [36] \\
\hline Orthopsittaca manilata & $\mathrm{X}$ & & Cross-species amplification, Genetic diversity & [36] \\
\hline Anodorhynchus hyacinthinus & $\mathrm{X}$ & $\mathrm{X}$ & $\begin{array}{l}\text { Cross-species amplification, Genetic diversity, } \\
\text { Population genetic structure }\end{array}$ & [41] [44] [46] \\
\hline Anodorhynchus leari & $\mathrm{X}$ & & Cross-species amplification, Genetic diversity & [46] \\
\hline Psittacus erithacus & & $\mathrm{X}$ & Loci isolation, Genetic diversity & [45] \\
\hline Cyanopsitta spixii & $\mathrm{X}$ & & Cross-species amplification, Genetic diversity & [46] \\
\hline Myiopsitta monachus & & $\mathrm{X}$ & $\begin{array}{l}\text { Loci isolation, Population genetic structure, Invasion } \\
\text { biology, Relatedness, Mating system }\end{array}$ & [47] [48] \\
\hline Cyanoliseus patagonus & & $\mathrm{X}$ & Loci isolation, Genetic diversity & [50] \\
\hline Poicephalus robustus & & $\mathrm{X}$ & Loci isolation, Genetic diversity & [23] \\
\hline Psittacula eques & $\mathrm{X}$ & $\mathrm{X}$ & $\begin{array}{l}\text { Loci isolation, Mating system, Population genetic } \\
\text { structure, Management, Reintroduction }\end{array}$ & [51]-[54] \\
\hline
\end{tabular}

lives in Solomon Island, New Guinea, Australia, Maluku Island and is not endangered [9]. Using these microsatellites, it was possible to study the mating system of the species, considering that there is a large number of males in each group. The study showed that the groups are not entirely composed of relatives and it seems that the composition of the groups occurred due to the lack of females throughout the years [15].

For another Australian parrot, the Budgerigar parakeet (Melopsittacus undulatus), 20 microsatellite loci were 
developed [16]. Although this parrot is not a threatened species, it is widely used in captivity and, therefore, is commonly removed from nature. This species can be used as a model for longevity due to its high relative oxygen consumption, high glucose level, and an above average body temperature [17].

A critically endangered parrot species, the Orange-bellied parrot (Neophema chrysogaster), from Australia and south-western Tasmania, was also genetically analyzed using microsatellite data [9]. Fourteen microsatellite loci were primarily developed in order to inform and monitor conservation efforts both in a captive breeding colony and in the remaining wild populations [18].

The endemic New Zealand specie Forbes' parakeet (Cyanoramphus forbesi) can hybridizes with the Chatham Island Redcrowned parakeet (C. novaezelandiae chathamensis). C. forbesi may still have an extremely small pure-bred adult population and it is therefore precautionary considered endangered. To measure the genetic variation in the Forbes' parakeet populations and to monitor its hybridization, six species-specific microsatellite loci were developed for Forbes's parakeet [19]. The microsatellites data permit to verify allele introgression of $C$. navazelandiae chathamensis [20]. It was also possible to test the designed microsatellite primers of Forbes' parakeet as heterologous PCR oligonucleotides in order to amplify microsatellite loci in two other Cyanoramphus species (C. auriceps and C. novaezelandiae novaezelandiae) [21].

The successful use of heterologous primers in other phylogenetically close species can reduce the financial costs of research. Using microsatellite loci that were developed for Forbes' parakeet (C. forbesi) [19], Eclectus parrot (Eclectus roratus) [14], St. Vincent Amazon (Amazona guildinguii) [22], Cape parrot (Poicephalus robustus robustus) [23], Carnaby's Black-cockatoo (Calyphorhynchus latirostris) [24], and Green-rumped parrotlet (Forpus passerines) [25], it was possible to study the complex of species Crimson rosella (Platycercus elegans) [26]. This complex has been considered as an example of the ring speciation hypothesis [27] and, together with the mitochondrial DNA, microsatellites were used to discuss its model in order to understand the history and the present genetic structure of this species [26]. Based on this research, the patterns of genetic diversity obtained for Platycercus elegans were compared [26] to the geographic variation in vocalization. The vocal variation in the species may coincide with areas of restricted gene flow among geographically continuous populations. The results also suggested that cultural traits can lead to reduced gene flow and promote speciation even without geographical barriers [28].

Concerning to parrots of Central and South America, microsatellite loci were developed for St. Vincent Amazon (Amazona guildinguii) [22] [29]. This specie is considered vulnerable and the microsatellites were used to estimate relatedness between captive individuals to assist in breeding programs maximizing gene diversity and minimizing inbreeding [30]. Other authors tested the primers developed for Amazona guildinguii [22] [29] in three other species of the genus: two endemic species of the Atlantic forest, the Red-tailed (A. brasiliensis) and the Red-spectacled (A. pretrei) amazons, are classified as vulnerable, and the Blue-fronted Amazon (A. aestiva) is not listed as a threatened species but it is intensively captured in wild areas for pet trade [31]. The polymorphic microsatellite loci of A. aestiva were used to compare the genetic diversity among four populations of Brazil and one populations of Argentina. The obtained data just evidenced a genetic structure between the populations on the extremity locations, and a clinal distribution of genetic diversity [32]. This information should be included in conservation strategies of this species. Microsatellite primers that were designed for Amazona guildinguii [22] [29] were also used on genetic analysis in order to detect cryptic diversity in the complex Cuban parrot (Amazona leucocephala) [33]. Besides, A. guildinguii designed microsatellite primers were also applied on Amazona auropalliata, revealing that there is no relationship between the genetic population structure and different dialects, in other words, high rates of gene flow were estimated between different vocal dialects [34].

Primers developed to St. Vincent Amazon [22] [29] and Blue-and-gold macaw [35] were re-designed to amplify smaller fragments and to be used with samples containing DNA of poor quality [36]. Moreover, amplification and polymorphism identification using these primers were tested in Blue- and-yellow macaw (Ara ararauna), Red- and green-macaw (Ara chloropterus), Scarlet macaw (Ara macao), Chestnut-fronted macaw (Ara severus), Red-bellied macaw (Orthopsittaca manilata), and mealy parrot (Amazona farinosa) [36]. The same primers were used in two critically endangered Neotropical parrots (Amazona collaria and Amazona agilis) to identify full sibling groups among individuals that had been confiscated due to illegal trade and were kept at the Vienna Zoo [37]. The obtained data will also serve to prioritize future breeding decisions in both species [36]. Moreover, the re-designed primers [36] were tested for microsatellites amplification in DNA samples extracted from feathers of Blue-and-yellow macaw (Ara ararauna), Red-and-green macaw (Ara chloropterus), and Scarlet macaw (Ara macao) [38], that were collected on the floor. This kind of non-invasive sampling is extremely 
useful on conservation biology analyses as it does not depend on capturing of the animals [38].

Another study developed five primer sets for amplification of microsatellites of the Cuban Amazon (Amazona leucocephala) [39]. Data on these loci may be used to answer questions about the species or other closely related species genetic variability, since it is considered vulnerable and has large regional dialects throughout its range in Central America.

Microsatellite primers that were designed for Chicken (Gallus gallus) [40] and for Hyacinth macaw (Anodorhynchus hyacinthinus) (Scott K. Davis, unpublished) were tested in Hyacinth macaw (A. hyacinthinus), Blueand-yellow macaw (Ara ararauna), Red-and-green macaw (Ara chloropterus), Red-spectacled amazon (Amazona pretrei), and Red-tailed amazon (Amazona brasiliensis). Only one of the chicken primers was monomorphic in all the analyzed species and both Hyacinth macaw primers were sucessfully applied in Hyacinth macaw and in the two Ara species. However, just one of these primers sets was able to amplify DNA segments in the genus Amazona [41]. The cross-species amplification and polymorphism are inversely related to the evolutionary distance between species [42].

Also concerning South American macaws, specific microsatellites [35] were used to study the population genetic structure of Blue-and-yellow macaw (Ara ararauna) [43]. No genetic differences were verified between different Brazilian populations using microsatellites data although some divergences could be identified by mitochondrial DNA analyzes. DNA markers that have distinct inheritance patterns and evolutionary rates can be used to elucidate different aspects of an species biology and, in the case of Ara araruna, male-biased dispersal and female philopatry could better explain the different patterns observed with microsatellites and mtDNA [43]. A population genetic structure study was also performed in Hyacinth macaw (Anodorhynchus hyacinthus), using both mitochondrial DNA and microsatellite loci revealing the existence of two distinct genetic groups in Brazil [44].

Microsatellites developed for St. Vincent Amazon [22] [29], Blue-and-yellow macaw [35] [36], and the African Grey Parrot (Psittacus erithacus) [45] were also tested in three endangered blue macaws from South America: Spix's macaw (Cyanopsitta spixii), Lear's macaw (Anodorhynchus leari), and Hyacinth macaw (Anodorhynchus hyacinthinus), and in two unthreatened macaws: Red-and-green macaw (Ara chloropterus), Scarlet macaw (Ara macao). The obtained data revealed that and many of them were polymorphic and, therefore, suitable for studies of kinship and population genetics [46].

Population analyses on invaders species can also be performed using microsatellite data. Species-specific Primers were developed for the Latin American Monk parakeet (Myiopsitta monachus) which corresponds to one of the most widely successful parrot invaders. Therefore, genetic diversity studies can elucidate aspects of its behavior and the genetic mechanisms involved in the success of the invasion [47]. A microsatellite genetic diversity analysis revealed a low loss of genetic variation at invasive sites compared to the native site and a relatedness pattern analysis evidenced a sexual monogamy in the species. These patterns directly and indirectly suggest that a high propagate pressure has contributed to Monk parakeet invasion success [48]. On the other hand, the Myiopsitta monachus native specimens in Argentina are not monogamous and the authors found significant levels of extra-pair copulation and nest parasitism, a scenario that could be favored by the high density of Monk parakeets in this region [49].

Still concerning South American parrots, microsatellite loci were isolated in the burrowing parrot (Cyanoliseus patagonus), a species that, although is not threatened, has population decline and is already extinct in places where it previously occurred [50].

With respect to African and Mauritius parrots, polymorphic microsatellite loci were characterized in the Cape parrot (Poicephalus robustus), an endemic species of Southern Africa. According to the authors, the generated microsatellite data can contribute to the illegal trade of the species [23]. Twelve microsatellite loci were also described for the African Grey parrot (Psitacus erithacus) [45], which is considered vulnerable [9] due to the extent of the harvest for international trade and habitat loss. These microsatellites loci were also investigated in Mauritius parakeet (Psittacula eques), an endangered species, which permitted to suggest the occurrence of extra-pair copulation. Breeding units often comprised a group of one female with more than one male, one of which was dominant and mated with and fed the female. This behavior can contribute with the extra-pair copulation [51].

The efficiency of microsatellite primers designed for the African Grey parrot [45] was successfully tested in Mauritius parakeet (Psittacula eques). Besides, other 21 microsatellite loci were developed for this species [52]. The analysis of genotype data derived from these species-specific microsatellite markers showed that Psittacula 
eques presented genetic differences among populations before their management and these differences disappeared after this human intervention [53]. This study shows that management can benefit populations of endangered species by reducing the risk of loss of genetic diversity [53]. Still using this species as a model, the genetic effects of population management (as reintroduction and translocation) were simulated under various scenarios both at the metapopulation and subpopulation levels [54]. This kind of information is very important to recommend management actions in order to avoid the loss of genetic diversity [54].

\section{Conclusion and Future Recommendation}

Although each species of parrot can present a distinct biological history, we can conclude that the genetic diversity assessment obtained by microsatellites is very useful in different aspects such as detecting differences in the genetic composition of populations, to understand evolutionary history, associate diversity genetics with vocal learning, find cryptic diversity, compare the genetic diversity of different species, verify extra-pair mating, among many other applications. Overall, this information may be used in conservation programs, since genetic data may prevent the loss of genetic diversity, a fact that is extremely correlated to the higher risk of species extinction. Despite this, we can conclude that the publications involving genetic diversity measurement using microsatellites are still rare in parrots, especially due to the high number of species of this animal group.

Birds conservation practices based on genetic data are increasingly necessary to address the impacts of human activities that have accelerated extinction and continue to threaten bird populations worldwide. Therefore, considerable research should be performed on parrots through the use of high polymorphic DNA markers, as microsatellites.

\section{References}

[1] Primack, R.B. and Rodrigues, E. (2002) Biologia da Conservação. Editora Rodrigues, Londrina.

[2] Bruford, M.W., Cheesman, D.J., Coote, T., Green, H.A.A., Haines, S.A., O’Ryan, C. and Williams, T.R. (1996) Microsatellite and Their Application to Conservation Genetics. In: Smith, T.B. and Wayne, R.K, Eds., Molecular Genetic Approaches in Conservation, Oxford University Press, New York, 278-297.

[3] Evans. S.R. and Sheldon, B.C. (2008) Interespecific Patterns of Genetic Diversity in Birds: Correlations with Extinction risk. Conservation Biology, 22, 1016-1025. http://dx.doi.org/10.1111/j.1523-1739.2008.00972.x

[4] Moritz, C. (1994) Defining Evolutionary Significant Units for Conservation. Trends in Ecology and Evolution, 9, 373-375. http://dx.doi.org/10.1016/0169-5347(94)90057-4

[5] Frankham, R., Ballou, J.D. and Briscoe, D.A. (2002) Introduction to Conservation Genetics. Cambridge University Press, Cambridge. http://dx.doi.org/10.1017/CBO9780511808999

[6] Avise, J.C. (1994) Molecular Markers, Natural History and Evolution. Chapman and Hall, New York. http://dx.doi.org/10.1007/978-1-4615-2381-9

[7] De Casteele, V.T., Galbusera, P. and Matthysen, E. (2001) A Comparison of Microsatellite-Based Pairwise Relatedness Estimator. Molecular Ecology, 10, 1539-1549. http://dx.doi.org/10.1046/j.1365-294X.2001.01288.x

[8] Collar, N.J. (1997) Family Psittacidae (Parrots). In: Del Hoyo, J., Elliot, A.E. and Sargatal, J., Eds., Handbook of the Birds of the World, Lynx Edicións, Barcelona, 280-477.

[9] BirdLife International (2012) In: IUCN 2013. IUCN Red List of Threatened Species. Version 2013.2. www.iucnredlist.org

[10] Laurance, W.F., Lovejoy, T.E., Vasconcelos, H.L., Bruna, E.M., Dirham, R.K., Stouffer, P.C., Gascon, C. Bierregaard Jr., R.O., Laurance, S.G. and Sampaio, E. (2002) Ecosystem Decay of Amazonian Forest Fragments: A 22-Year Investigation. Conservation Biology, 16, 605-618. http://dx.doi.org/10.1046/j.1523-1739.2002.01025.x

[11] Munn, C.A. (1992) Macaw Biology and Ecotourism, or When a Bird in the Bush Is Worth Two in the Hand. In: Beissinger, S.R. and Snyder, N.F.R., Eds., New World Parrots in Crisis: Solutions from Conservation Biology, Smithsonian Institution Press, Washington DC, 47-72.

[12] Wright, T.F., Toft, C.A., Enkerlin-Hoeflich, E., Gonzalez-Elizondo, J., Albornoz, M., Rodríguz-Ferraro, A., RojasSuárez, F., Sanz, V., Trujillo, A., Beissinger, S.R., Berovides, A.V., Gálvez, A.X., Brice, A.T., Joyner, K., Eberhard, J., Gilardi, J., Koenig, S.E., Stoleson, S., Martuscelli, P., Meyers, J.M., Renton, K., Rodríguez, A.M., Sosa-Asanza, A.C., Vilella. F.J. and Wiley, J.W. (2001) Nest Poaching in Neotropical Parrots. Conservation Biology, 15, 710-720. http://dx.doi.org/10.1046/j.1523-1739.2001.015003710.x

[13] Masello, J.F. and Quillfeldt, P. (2002) Chick Growth and Breeding Success of the Burrowing Parrot. Condor, 104, 
574-586. http://dx.doi.org/10.1650/0010-5422(2002)104[0574:CGABSO]2.0.CO;2

[14] Adcock, G.J., Heinsohn, R., Ebert, D., Amini, N. and Peakall, R. (2005) Microsatellite Loci for Behavioural Studies of Eclectus Parrot (Eclectus roratus: Aves). Molecular Ecology Notes, 5, 616-618. http://dx.doi.org/10.1111/j.1471-8286.2005.01014.x

[15] Heinsohn, R., Ebert, D., Legge, S. and Peakall, R. (2007) Genetic Evidence for Cooperative Polyandry in Reverse Dichromatic Eclectus Parrots. Animal Behavior, 74, 1047-1054. http://dx.doi.org/10.1016/j.anbehav.2007.01.026

[16] Kamara, D., Geng, T., Xu, J., Guynn, S., Hopwood, K. and Smith, E.J. (2007) Isolation and Characterization of Microsatellite Markers from the Budgerigar, Melopsittacus undulatus. Molecular Ecology Notes, 7, 507-509. http://dx.doi.org/10.1111/j.1471-8286.2006.01636.x

[17] Austad, S.N. (1997) Birds as Models of Aging in Biomedical Research. ILAR Journal, 38, 137-141. http://dx.doi.org/10.1093/ilar.38.3.137

[18] Miller, A.D., Good, R.T., Coleman, R.A., Lancaster, M.L. and Weeks, A.R. (2013) Microsatellite Loci and the Complete Mitochondrial DNA Sequence Characterized through Next Generation Sequencing and de Novo Genome Assembly for the Critically Endangered Orange-Bellied Parrot, Neophema chrysogaster. Molecular Biology Reports, 40, 35-42. http://dx.doi.org/10.1007/s11033-012-1950-z

[19] Chan, C.-H., Ballantyne, K.N., Lambert, D.M. and Chambers, G.K. (2005) Characterization of Variable Microsatellite Loci in Forbes' Parakeet (Cyanoramphus forbesi) and Their Use in Other Parrots. Conservation Genetics, 6, 651-654. http://dx.doi.org/10.1007/s10592-005-9021-9

[20] Chan, C.-H., Ballantyne, K.N., Aikman, H., Fastier, D., Daugherty, C.H. and Chambers, G.K. (2006) Genetic Analysis of Interspecific Hybridisation in the World's Only Forbes' Parakeet (Cyanoramphus forbesi) Natural Population. Conservation Genetics, 7, 493-506. http://dx.doi.org/10.1007/s10592-005-9060-2

[21] Chan, C.-H., Zhao, Y. and Chambers, G.K. (2009) Microsatellite DNA Markers Provide Informative Genetic Data for Studies on New Zealand Cyanoramphus Parakeets. New Zealand Natural Sciences, 34, 69-76.

[22] Russello, M.A., Calcagnotto, D., DeSalle, R. and Amato, G. (2001) Characterization of Microsatellite Loci in the Endangered St. Vicent Parrot, Amazona guildingii. Molecular Ecology Notes, 1, 13-15.

http://dx.doi.org/10.1046/j.1471-8278 .2001.00061.x

[23] Pillay, K., Dawson, D.A., Horsburgh, G.J., Perrin, M.R., Burke, T. and Taylor, T.D. (2010) Twenty-Two Polymorphic Microsatellite Loci Aimed at Detecting Illegal Trade in the Cape Parrot, Poicephalus robustus (Psittacidae, Aves). Molecular Ecology Resources, 10, 142-149. http://dx.doi.org/10.1111/j.1755-0998.2009.02673.x

[24] McInnes, L.M., Dadour, I.R., Stewart, M., Ditcham, W.G., Mawson, P. and Spencer, P.B. (2005) Characterization of Polymorphic Microsatellite Markers for the Carnaby's Cockatoo (Calyptorhynchus latirostris) and Related Black Cockatoo Species. Molecular Ecology Notes, 5, 504-506. http://dx.doi.org/10.1111/j.1471-8286.2005.00971.x

[25] Hughes, C.R., Meland, R.R. and Beissinger, S.R. (1998) Polymorphic Trinucleotide Microsatellite Loci for Neotropical Parrot, the Green-Rumped Parrotlet, Forpus passerinus. Molecular Ecology, 7, 1247-1248.

[26] Joseph, L., Dolman, G., Donnellan, S., Saint, K.M., Berg, M.L. and Bennet, A.T.D. (2008) Where and When Does a Ring Start and End? Testing the Ring-Species Hypothesis in a Species Complex of Australian Parrots. Proceedings of the Royal Society B: Biological Sciences, 275, 2431-2440.

[27] Irwin, D.E. and Irwin, J.H. (2002) Circular Overlaps: Rare Demonstrations of Speciation. The Auk, 119, 596-602.

[28] Ribot, R.F.H., Buchanan, K.L., Endler, J.A., Joseph, L., Bennett, A.T.D. and Berg, M.L. (2012) Learned Vocal Variation Is Associated with Abrupt Cryptic Genetic Change in a Parrot Species Complex. PLoS ONE, 7, e50484. http://dx.doi.org/10.1371/journal.pone.0050484

[29] Russello, M., Lin, K. Amato, G. and Caccone, A. (2005) Additional Microsatellite Loci for the Endangered St. Vincent Parrot, Amazona guildingii. Conservation Genetics, 6, 643-645. http://dx.doi.org/10.1007/s10592-005-9019-3

[30] Russello, M.A. and Amato, G. (2004). Ex Situ Population Management in the Absence of Pedigree Information. Molecular Ecology, 13, 2829-2840. http://dx.doi.org/10.1111/j.1365-294X.2004.02266.X

[31] Caparroz, R., Leite, K.C.E., Chinalia, L.A., Myiaki, C.Y. and Collevatti, R.G. (2007). Characterization of Microsatellite Loci in Three Species of Amazona (Psittaciformes) Using Heterologous Primers. Ornitologia Neotropical, 18, 439-444.

[32] Leite, K.C.E., Seixas, G.H.F., Berkunsky, I., Collevatti, R.G. and Caparroz, R. (2008) Population Genetic Structure of the Blue-Fronted Amazon (Amazona aestiva, Psittacidae: Aves) Based on Nuclear Microsatellite Loci: Implications for Conservation. Genetics and Molecular Research, 7, 819-829. http://dx.doi.org/10.4238/vol7-3gmr474

[33] Russello, M.A, Stahala, C., Lalonde, D., Schmidt, K.L. and Amato, G. (2010) Cryptic Diversity and Conservation Units in the Bahamas Parrots. Conservation Genetics, 11, 1809-1821. http://dx.doi.org/10.1007/s10592-010-0074-z

[34] Wright, T.F., Rodriguez, A.M. and Fleischer, R.C. (2005) Vocal Dialect, Sex-Biased Dispersal and Microsatellite Pop- 
ulation Structure in the Parrot Amazona auropalliata. Molecular Ecology, 14, 1197-1205. http://dx.doi.org/10.1111/j.1365-294X.2005.02466.x

[35] Caparroz, R., Miyaki, C.Y. and Baker, A.J. (2003) Characterization of Microsatellite Loci in the Blue-and-Gold Macaw, Ara ararauna (Psittaciformes: Aves). Molecular Ecology Notes, 10, 1046-1048.

[36] Gebhardt, K.J. and Waits, L.P. (2008) Cross-Species Amplification and Optimization of Microsatellite Markers for Use in Six Neotropical Parrots. Molecular Ecology Resources, 4, 835-839. http://dx.doi.org/10.1111/j.1755-0998.2007.02083.x

[37] Ringler, E. (2012) The Use of Cross-Species Testing of Microsatellite Markers and Sibship Analysis in ex Situ Population Management. Conservation Genetic Resource, 4, 815-819. http://dx.doi.org/10.1007/s12686-012-9642-5

[38] Gebhardt, K.J., Brightsmith, D. Powell, G. and Waits, L.P. (2009) Molted Feathers from Clay Licks in Peru Provide DNA for Three Large Macaws (Ara ararauna, A. chloropterus, and A. macao). Journal of Field Ornithology, 80, 183-192. http://dx.doi.org/10.1111/j.1557-9263.2009.00221.x

[39] Taylor, T.D. and Parkin, D.T. (2007) Characterization of 13 Microsatellite Loci for the Moluccan Cockatoo, Cacatua moluccensis, and Cuban Amazon, Amazona leucocephala, and Their Conservation and Utility in Other Parrot Species (Psittaciformes). Conservation Genetics, 8, 991-994. http://dx.doi.org/10.1007/s10592-006-9211-0

[40] Gibbs, M., Dawson, D.A., McCamley, C., Wardle, A.F., Armour, J.A.L. and Burke, T. (1997) Chicken Microsatellite Markers Isolated from Libraries Enriched for Simple Tandem Repeats. Animal Genetics, 28, 401-418. http://dx.doi.org/10.1111/j.1365-2052.1997.00184.X

[41] Faria, P.J. and Miyaki, C.Y. (2006) Molecular Markers for Population Genetic Analyses in the Family Psittacidae (Psittaciformes, Aves). Genetics and Molecular Biology, 29, 231-240. http://dx.doi.org/10.1590/S1415-47572006000200007

[42] Primmer, C.R., Painter, J.N., Koskinen, M.T., Palo, J.U. and Merilä, J. (2005) Factors Affecting Avian Cross-Species Microsatellite Amplification. Journal of Avian Biology, 36, 348-360. http://dx.doi.org/10.1111/j.0908-8857.2005.03465.x

[43] Caparroz, R., Miyaki, C. and Baker, A.J. (2009) Contrasting Phylogeographic Patterns in Mitochondrial DNA and Microsatellite: Evidence of Female Philopatry and Male-Biased Gene Flow among Regional Populations of the Blueand-Yellow Macaw (Psittaciformes: Ara ararauna) in Brazil. The Auk, 126, 359-370. http://dx.doi.org/10.1525/auk.2009.07183

[44] Faria, P.J., Guedes, N.M.R., Yamashita, C., Martuscelli, P. and Miyaki, C.Y. (2007) Genetic Variation and Population Structure of the Endangered Hyacinth Macaw (Anodorhynchus hyacinthinus): Implications for Conservation. Biodiversity and Conservation, 17, 765-779. http://dx.doi.org/10.1007/s10531-007-9312-1

[45] Taylor, T.D. and Parkin, D.T. (2007) Characterization of 12 Microsatellite Primer Pairs for the African Grey Parrot, Psittacus erithacus and Their Conservation across the Psittaciformes. Molecular Ecology Notes, 7, 163-167. http://dx.doi.org/10.1111/j.1471-8286.2006.01566.x

[46] Presti, F.T., Oliveira-Marques, A.R., Caparroz, R., Biondo, C. and Miyaki, C.Y. (2011) Comparative Analysis of Microsatellite Variability in Five Macaw Species (Psittaciformes, Psittacidae): Application for Conservation. Genetics and Molecular Biology, 34, 348-352. http://dx.doi.org/10.1590/S1415-47572011005000012

[47] Russello, M.A., Saranathan, V., Buhrman-Deever, S., Eberhard, J. and Caccone, A. (2007) Characterization of Polymorphic Microsatellite Loci for the Invasive Monk Parakeet (Myiopsitta monachus). Molecular Ecology Notes, 7, 990-992. http://dx.doi.org/10.1111/j.1471-8286.2007.01749.x

[48] Gonçalves da Silva, A., Eberhard, J.R., Wright, T.F., Avery, M.F. and Rusello, M.A. (2008) Genetic Evidence for High Propagule Pressure and Long-Distance Dispersal in Monk Parakeet (Myiopsitta monachus) Invasive Populations. Molecular Ecology, 19, 3336-3350. http://dx.doi.org/10.1111/j.1365-294X.2010.04749.x

[49] Martínez, J.J., Aranzamendi, M.C., Masello, J.F. and Bucher, E.H. (2013) Genetic Evidence of Extra-Pair Paternity and Intraspecific Brood Parasitism in the Monk Parakeet. Frontiers in Zoology, 10, 68-74. http://dx.doi.org/10.1186/1742-9994-10-68

[50] Klauke, N., Masello, J.F., Quillfeldt, P. and Segelbacher, G. (2009) Isolation of Tetranucleotide Microsatellite Loci in the Burrowing Parrot (Cyanoliseus patagonus). Journal of Ornithology, 150, 921-924. http://dx.doi.org/10.1007/s10336-009-0423-1

[51] Taylor, T.D. and Parkin, D.T. (2009) Preliminary Evidence Suggests Extra-Pair Mating in the Critically Endangered Echo Parakeet Psittacula eques. African Zoology, 44, 71-74. http://dx.doi.org/10.3377/004.044.0107

[52] Raisin, C., Dawson, D.A., Greenwood, A.G., Jones, C.G. and Groombridge, J.J. (2009) Characterization of Mauritius Parakeet (Psittacula eques) Microsatellite Loci and Their Cross-Utility in Other Parrots (Psittacidae, Aves). Molecular Ecology Resource, 9, 1231-1235. http://dx.doi.org/10.1111/j.1755-0998.2009.02621.X

[53] Raisin, C., Frantz, A.C., Kundu, S., Greenwood, A.G., Jones, C.G., Zuel, N. and Groombridge, J.J. (2012) Genetic 
Consequences of Intensive Conservation Management for the Mauritius Parakeet. Conservation Genetics, 13, 707-715. http://dx.doi.org/10.1007/s10592-012-0319-0

[54] Tollington, S., Jones, C.G., Greenwood, A., Tatayah, V., Raisin, C., Burke, T., Dawson, D.A. and Groombridge, J.J. (2013) Long-Term, Fine-Scale Temporal Patterns of Genetic Diversity in the Restored Mauritius Parakeet Reveal Genetic Impacts of Management and Associated Demographic Effects on Reintroduction Programmes. Biological Conservation, 161, 28-38. http://dx.doi.org/10.1016/j.biocon.2013.02.013 